\title{
Reliability and Validity of "Parents' Evaluation of Responsible Behaviors of 5-6 Year Old Children" Scale
}

\author{
Ozgul Polat $^{1} \&$ Asude B. Dağal ${ }^{1}$ \\ ${ }^{1}$ School of Preschool Education, Marmara University, İstanbul, Turkey \\ Correspondence: Asude Balaban Dağal, School of Preschool Education, Marmara University, Atatürk Education \\ Faculty,Göztepe, İstanbul, Turkey. Tel: 90-216-566-0112. E-mail: asudebd@ marmara.edu.tr
}

\author{
Received: February 8, 2013 Accepted: February 22, 2013 Available online: March 29, 2013 \\ doi:10.11114/jets.v1i1.113 URL: http://dx.doi.org/10.11114/jets.v1i1.113
}

\begin{abstract}
This study is aimed at developing a scale (Parents' Evaluation of Responsible Behaviors Of 5-6 Year Old Children) for measuring parents' evaluation of their 5-6 year-old children's responsible behaviors . The construct validity of the scale was tested by Factor Analysis. Factor analysis determined that the scale can be clustered under 10 factors. Item total correlations were calculated and independent samples t-test was conducted in order to determine the presence of a meaningful difference between the top and the bottom $\% 27$ groups. The reliabilities of the scale and their subscales were analysed by using Cronbach Alpha technique. Cronbach Alpha of the whole scale is 0,92 . And cronbach alpha analysis of the subscales were also so high. Also split half and test-retest reliability analyses were done. $1^{\text {st }}$ Section reliability was found as Alfa: 0,83 and $2^{\text {nd }}$ Section reliability as Alfa: 0, 90.The results showed that the scale had good psychometric properties and thus could be used to assess the responsibility behaviors of 5-6 year olds.
\end{abstract}

Keywords: preschool children, responsibility behavior, parent's evaluation of responsible behavior scale

\section{Introduction}

\subsection{Problem}

Moral development targets at adopting societal values in children and thus letting them adapt to the society more easily. Moral development is awareness of how to behave in public. Learning our duties and responsibilities towards people we live with is a part of moral development (Özden, 2005). In children conscience, meaning separating the good from bad is limited with orders and bans of parents or those that take their place. Children do not yet make a mental contribution themselves. As children grow up, they start taking orders from their hearts and minds. What upsets and pleases their parents or others close to them add in their understanding of good and bad. Afterwards, self respect and respect for others, personality, duties and responsibilities, and virtue slowly form and develop and improve the children's understanding (Aydın, 2003; akt. Balat, Dağal, 2006).

Every child is born in a society and has to learn rules and social roles determined by that society. Children cannot act as competitive members of the society without understanding these social categories and rules (Zembat \& Unutkan, 2001).

Studies show that most of the learning of children takes place in 0-6 years of age and this is the period when basic skills to adapt to life are either gained or laid foundations of. In this period the individual starts to get socialized and establish relationships with other people which make gaining some behaviors earlier even more important (Polat, 2005). As in other learning types in socialization the children are not only passive receivers of pressure to behave in a certain way. They try to understand what is asked of them and behave accordingly (Katz, 1984, p.27). In early ages when the individual starts socializing and communicating with others, it is important that certain behaviors are learned earlier. In order to carry the responsibility of being an individual and manage relations with others, the children must be supported as much as their skills allow for. When children are not given responsibilities, they are found to have others do their work and not be uncomfortable with this at all. It is normal for children that are raised in this way to feel weak and insecure in their future lives (Polat, 2005).

Responsibility starts in the early childhood period by giving children duties according to their age, gender, and level of development. Allowing for the two and a half year old child to drink soup by oneself, expecting the child 
to tidy up his/her own toys, preparing the child's room and bed to sleep in, expecting the child's help on chores such as preparing the dinner table or cleaning the car according to the child's age and gender prepares an encouraging and supportive environment about "responsibility". Such an environment would allow for the child to feel himself/herself enough for and manage him/herself and increase self-confidence (Yavuzer, 2008, p.107).

Lickona (1992) defined responsibility as an enlarged version of respect. Lickona continued to argue that being responsible would require succeeding on a job or duty in the family, school, and work life. Lickona (1992) mentioned that character training is a must for all democratic and free societies. According to this, not only schools, but also societies have the responsibility to give this training. This responsibility necessitates effective teaching of two basic values at schools. The first one is "the respect" that requires giving value to humans, other creatures, and the natural environment while the second one is "the responsibility" that requires to be accountable for and accepting the results of own behaviors and succeeding at own duties. Thus, these two values are required for all social structures from school to the state (akt; Akbaş, 2008).

None of us are born with a sense of responsibility. Responsible character matures in time. Daily habits and point of view related with feelings, thoughts, and actions make up responsibility. Responsible individuals act consistently whether or not they are observed by someone. They act in this way because they know this is the correct way of action and they have control and courage to act politely even though they consider acting in a different way (Rebarber, 2010).

Children learn responsibility in three ways. The first and the most important way is learning by observing. The second is by training. The third is learning by reflections of their own experiences and good thinking in their lives. Children are taught things with words and actions at all times. Children learn by hearing, seeing, and eavesdropping. They learn from us, from each other, from other adults, and from themselves (Rebarber, 2010).

Preschool education has many purposes. Preparing the children for life and primary education is one of the main purposes of preschool education. The children must have many basic skills and qualifications to succeed in life and primary education. Being responsible is one of such qualifications. Children with a sense of responsibility would have higher successes both during their primary education and in life. Family is the main institution where responsibility begins. For this reason, it is very important that children are consciously given responsibilities during preschool period when most of the learning takes place while activities about responsibility training are intensely given in parent participation programs and educators follow their applications by the parents. There is a need for measurement devices to evaluate the level of responsibility children have. It is very important that levels of responsibility children have are evaluated in preschool period and the necessary supports are provided (Polat, 2010).

All adults want their children to grow up to become responsible individuals. However, responsibility is not a character trait that develops on its own. It is obvious that families play a major part at least as the preschool institutions play in education of children to let them become responsible individuals. Adult attitudes, behaviors, and small responsibilities given to children in home environment contribute to development of responsibility in individuals. For this reason, scales are required to measure the level of responsibilities families give to their children at home. Because responsibility is closely related with success children would attain in life and is at the foundation of life. Families have a major role in giving responsibility to children. It can be argued that during the preschool period when most of the education takes place, contribution of parents would help raise responsible individuals.

However, when the literature is investigated, no scale that measures parental observations of children's responsible behaviors is found. Aim of this study is to develop a scale directed to family opinions about children's responsible behaviors. By this way, the place reserved for responsibility in the education that parents give to their children and parental evaluation of their children's responsible behaviors can be discussed.

The aim of this study is to develop a scale for measuring "parents' evaluation of their 5-6 year-old children's responsible behaviors".

For this porpose, the answers for the following two questions have to be found:

1. Is "parents' evaluation of their 5-6 year-old children's responsible behaviors" scale valid?

2. Is "parents' evaluation of their 5-6 year-old children's responsible behaviors" scale reliable?

\subsection{Significance of the Study}

This research is significant because it

1. Facilitates the development of a new scale for the responsibility behaviours of 5-6 year old children 
2. Provides guidance for new studies on this subject

3. Demonstrates the need for the inclusion of responsible behaviour concepts in preschool education programmes

4. Lets the teachers realize their students' responsibility skills

Also by applying this scale in the later periods, the level of responsibility parents give to their children at home might be determined and supportive programs can be proposed. In this case, correct guidance can be provided to families while they raise their children.

\section{Method}

\subsection{Research Model}

The research is about the development of a scale based on the tests of reliability and validity analysis.

\subsection{Working Group}

A total of 588 children between 5-6 years of age participated in this study. The working group is randomly chosen from student groups attending public and private kindergartens in Asia and Europe sides of Istanbul. Validity and reliability analyses are applied on this chosen group.

\subsection{Measurement Tool}

\subsubsection{Preparing Scale Items}

Establishment of the scale started with its items. Firstly the items were chosen from the responsibility behaviors which are at the literature and also that can be applied by the 5-6 year old children and also can be seen by their parents. And after that the item pool was created. The created items were converted to proper form after examination of two experts on preschool teaching.

\subsubsection{Data Collection Tools}

Parents' Evaluation of Responsible Behaviors Of 5-6 Year Old Children Scale (PERBC): The scale is composed of items related with parental observation of responsibility behaviors by children that attend a certain institution in the preschool period. Items cover responsibilities that preschool children take at home, towards the environment, in class, and towards their bodies.

"Parents' Evaluation of Responsibile Behaviors of 5-6 Year Old Children Scale" is a 50-item form at first. The items were prepared after taking expert opinions. Pre-study for the 50-item form was made in Marmara University Preschool Application Unit and no items were removed at that stage. But after the validity and reliability analysis the scale was reduced to 41 items. Some of the scale items are mentioned below:

Item-6: Washes hands after eating.

Item-16: Reminds parents of responsibilities given by teacher.

Item-19: Teacher says that the child is responsible towards the environment.

Item-23: When someone asks the child of something, the child would not forget the request and performs it.

Item-35: Does not waste water.

Factor analysis determined that the scale can be clustered under 10 factors. Below are these factors:

Factor 1: Responsibilities towards the living environment

Factor 2: Continuing with the responsibility that the child assumed

Factor 3: Responsibilities towards objects

Factor 4: Responsibility towards the natural environment

Factor 5: Responsibilities about hygiene

Factor 6: Responsibilities at home

Factor 7: Responsibilities towards the society

Factor 8: Responsibilities towards others

Factor 9: Responsibilities towards bodily needs

Factor 10: Responsibilities regarding energy saving

This scale which was prepared for the parents were completed by the parents by using an " $\mathrm{x}$ " sign next to the 
option they found appropriate among five different options that represented "5 always", "4 often", "3 sometimes", "2 rarely", and "1 never".

\subsection{Validity Studies of the Scale}

Factor analysis was applied to the data to determine factor structure of the scale. The correlation analysis was applied for every item under the subscales. And also independent samples t-test was conducted in order to determine the meaningful difference between the top and the bottom $\% 27$ groups.

\subsection{Reliability Studies of the Scale}

Internal reliability coefficients of the complete scale and its sub-tests that were applied on 588 people were calculated using the Cronbach Alpha method. Also the scale was repeated on a 30-person group after two weeks. Test-retest reliability analyses were performed with the data. Thus, time resistance of the scale was determined.

\subsection{Data Collection}

Schools were chosen from Asian and European sides of Istanbul for the reliability and validity studies of the scale and the scale was distributed to parents with the help of principals and teachers.

\section{Findings and Comments}

\subsection{Findings about Validity}

\subsubsection{Findings about Factor Analysis}

Information about the results of factor analysis is given on table 1 below.

Table 1. KMO and Bartlett's Test

\begin{tabular}{lll}
\hline \multicolumn{2}{l}{ Kaiser-Meyer-Olkin Measure of Sampling Adequacy. } & .875 \\
\hline \multirow{3}{*}{ Bartlett's Test of Sphericity } & Approx. Chi-Square & 6566.227 \\
& Df & 561 \\
& Sig. & .000 \\
\hline
\end{tabular}

As it is seen on Table 1, the KMO value that determines the sample's qualification for factor analysis is above 0,50 and also Barlett test is at 0,05 significance level for the analysis $\left(\mathrm{KMO}=.875, x^{2}\right.$ Barlett test $(561)=6566.22$; $\mathrm{p}=, 000$ ). These values show that, the data is excellently suitable for factor analysis and scale variables can be estimated from each other perfectly because of the KMO value achieved.

Measure of Sampling Adequacy that determine the suitability of each item for factor analysis was studied. If Measure of Sampling Adequacy (MSA) value is less than 0.50 the relative question must be removed from the scale (Sipahi,Yurtkoru ve Çinko, 2006). As a result of the MSA analysis none of the items were knocked out of the scale.

Table 2. Parents' Examination of Responsible Behaviors Of 5-6 Year Old Children's Scale' and Subtests Variance Ratios and Eigen Values

\begin{tabular}{lrrr}
\hline & & Initial Eigen Values & \\
\hline 1 & Total & \% of Variance & Cumulative \% \\
2 & 10.274 & 25.058 & 25.058 \\
3 & 2.401 & 5.856 & 30.915 \\
4 & 2.033 & 4.959 & 35.874 \\
5 & 1.716 & 4.185 & 40.058 \\
6 & 1.580 & 3.853 & 43.911 \\
7 & 1.470 & 3.585 & 47.496 \\
8 & 1.410 & 3.440 & 50.936 \\
9 & 1.217 & 2.969 & 53.905 \\
10 & 1.181 & 2.882 & 56.787 \\
\hline
\end{tabular}

Table 2 shows Eigen values of children responsibility scale. According to the results of the analysis, we can see that scale items are collected under 10 dimensions. Varimax rotation was used to determine the essential 
components. The amount of total variance was $\%$ 59.37. Factor analysis of variance ratios ranging from $60 \%$ to $40 \%$ is considered to be ideal (Scherer, 1988; akt. Erdoğan, Bayram, Deniz, 2007). It can be said that, in this study, the amount of the total variance is at an adequate level.

In Table 3 arithmetic mean and standard deviation values for every item are given.

Table 3. Arithmetic Means and Standard Deviations of the Items

\begin{tabular}{|c|c|c|c|c|c|}
\hline & $\mathrm{N}$ & Minimum & Maximum & Mean & SS \\
\hline os 1 & 587 & 1.00 & 5.00 & 3.84 & .94 \\
\hline os2 & 586 & 1.00 & 5.00 & 4.42 & .90 \\
\hline os5 & 586 & 1.00 & 5,00 & 4.37 & .85 \\
\hline os6 & 586 & 1.00 & 5.00 & 4.25 & .94 \\
\hline os7 & 587 & 1.00 & 5.00 & 4.64 & .67 \\
\hline os 8 & 586 & 1.00 & 5.00 & 3.96 & 1.21 \\
\hline os9 & 587 & 1.00 & 5.00 & 4.02 & 1.06 \\
\hline os 10 & 587 & 1.00 & 5.00 & 4.04 & 1.02 \\
\hline os11 & 581 & 1.00 & 5.00 & 3.92 & 1.15 \\
\hline os 12 & 586 & 1.00 & 5.00 & 4.23 & .86 \\
\hline os 14 & 587 & 1.00 & 5.00 & 4.08 & 1.49 \\
\hline os 15 & 587 & 1.00 & 5.00 & 3.70 & 1.30 \\
\hline os 16 & 587 & 1.00 & 5.00 & 4.38 & .94 \\
\hline os 17 & 582 & 1.00 & 5.00 & 3.96 & 1.13 \\
\hline os 19 & 581 & 1.00 & 5.00 & 3.90 & 1.19 \\
\hline os 20 & 587 & 1.00 & 5.00 & 4.45 & .93 \\
\hline os 21 & 587 & 1.00 & 5.00 & 4.45 & .83 \\
\hline os 22 & 586 & 1.00 & 5.00 & 4.33 & .87 \\
\hline os 23 & 587 & 1.00 & 5.00 & 4.12 & .90 \\
\hline os 24 & 587 & 1.00 & 5.00 & 3.70 & 1.04 \\
\hline os 25 & 587 & 1.00 & 5.00 & 3.41 & 1.13 \\
\hline os26 & 583 & 1.00 & 5.00 & 2.90 & 1.18 \\
\hline os 27 & 583 & 1.00 & 5.00 & 3.71 & 1.20 \\
\hline os 28 & 583 & 1.00 & 5.00 & 3.98 & 1.04 \\
\hline os 29 & 583 & 1.00 & 5.00 & 3.53 & 1.11 \\
\hline os30 & 583 & 1.00 & 5.00 & 3.63 & 1.09 \\
\hline os 31 & 582 & 1.00 & 5.00 & 3.40 & 1.19 \\
\hline os 32 & 583 & 1.00 & 5.00 & 3.96 & .97 \\
\hline os 33 & 580 & 1.00 & 5.00 & 3.45 & 1.31 \\
\hline os34 & 583 & 1.00 & 5.00 & 3.41 & 1.27 \\
\hline os 35 & 582 & 1.00 & 5.00 & 3.87 & 1.20 \\
\hline os 36 & 582 & 1.00 & 5.00 & 4.03 & 1.12 \\
\hline os 37 & 583 & 1.00 & 5.00 & 3.98 & .96 \\
\hline os39 & 583 & 1.00 & 5.00 & 3.95 & 1.09 \\
\hline os 40 & 583 & 1.00 & 5.00 & 3.88 & 1.11 \\
\hline os41 & 582 & 1.00 & 5.00 & 4.25 & .98 \\
\hline os 42 & 582 & 1.00 & 5.00 & 4.21 & .95 \\
\hline os44 & 582 & 1.00 & 5.00 & 3.61 & 1.19 \\
\hline os 45 & 583 & 1.00 & 5.00 & 3.59 & 1.21 \\
\hline os 46 & 583 & 1.00 & 5.00 & 3.47 & 1.18 \\
\hline os48 & 583 & 1.00 & 5.00 & 3.94 & 1.04 \\
\hline Valid N (list wise) & 562 & & & & \\
\hline
\end{tabular}

Factor matrices for items of the scale are shown in Table 3. Arithmetic averages ranged from 2.90 to 4.45 . Standard deviations ranged from 1.31 to 0.68 . 
Table 4. Factor Matrix Rotated Component Matrix

\begin{tabular}{|c|c|c|c|c|c|c|c|c|c|c|}
\hline & & & & & Comp & & & & & \\
\hline & 1 & 2 & 3 & 4 & 5 & 6 & 7 & 8 & 9 & 10 \\
\hline os 28 & .700 & & & & & & & & & \\
\hline os 29 & .672 & & & & & & & & & \\
\hline os30 & .645 & & & & & & & & & \\
\hline os 27 & .640 & & & & & & & & & \\
\hline os 45 & .612 & & & & & & & & & \\
\hline os26 & .602 & & & & & & & & & \\
\hline os32 & .518 & & & & & & & & & \\
\hline os46 & & .631 & & & & & & & & \\
\hline os 44 & & .627 & & & & & & & & \\
\hline os 48 & & .626 & & & & & & & & \\
\hline os33 & & .558 & & & & & & & & \\
\hline os34 & & .517 & & & & & & & & \\
\hline os37 & & .367 & & & & & & & & \\
\hline os39 & & & .678 & & & & & & & \\
\hline os 10 & & & .677 & & & & & & & \\
\hline os 22 & & & .651 & & & & & & & \\
\hline os42 & & & .500 & & & & & & & \\
\hline os 21 & & & .484 & & & & & & & \\
\hline os 17 & & & & .824 & & & & & & \\
\hline os 19 & & & & .795 & & & & & & \\
\hline os11 & & & & .767 & & & & & & \\
\hline os 12 & & & & .564 & & & & & & \\
\hline os5 & & & & & .717 & & & & & \\
\hline os6 & & & & & .680 & & & & & \\
\hline os 2 & & & & & .679 & & & & & \\
\hline os 1 & & & & & .536 & & & & & \\
\hline os7 & & & & & .524 & & & & & \\
\hline os24 & & & & & & .846 & & & & \\
\hline os 25 & & & & & & .832 & & & & \\
\hline os31 & & & & & & .475 & & & & \\
\hline os8 & & & & & & .416 & & & & \\
\hline os 20 & & & & & & & .761 & & & \\
\hline os 16 & & & & & & & .746 & & & \\
\hline os 23 & & & & & & & .445 & & & \\
\hline os 14 & & & & & & & & .886 & & \\
\hline os 15 & & & & & & & & .884 & & \\
\hline os41 & & & & & & & & & .693 & \\
\hline os 40 & & & & & & & & & .597 & \\
\hline os9 & & & & & & & & & .554 & \\
\hline os36 & & & & & & & & & & .696 \\
\hline os 35 & & & & & & & & & & .565 \\
\hline
\end{tabular}


Results of the factor analysis regarding family responsibility scale for preschool children are given in Table 4 . Scale items that were collected under 10 dimensions according to the results of factor analysis are distributed according to the dimensions as follows: 1 . dimension 7, 2. dimension 6,3 . dimension 5 , 4. dimension 4, 5 . Dimension 5, 6. dimension 4, 7. dimension 2, 8.dimension 3, 9. dimension 3, and 10. dimension 2 items.

The classification was evaluated as it was when the $38^{\text {th }}$ item was removed. After this item was left out of analysis $3^{\text {rd }}, 18^{\text {th }}, 47^{\text {th }}, 49^{\text {th }}, 50^{\text {th }}, 43^{\text {rd }}$, and the $4^{\text {th }}$ items were found to have low distinctiveness since they had almost equal weighting with other factor groups and they were taken off the question list in this order. In sub factor reliability analysis $13^{\text {th }}$ factor was also left out which led to increased Cronbach Alpha value of factor 7 . Thus this item was also left out of analysis.

Items correlations between the factors items were also analysed. The results of the correlations are shown at the tables below.

Table 5. The Correlations of Items under Factor 1 (Responsibilities Towards Living Environment)

\begin{tabular}{llrrrrrrr}
\hline & & os26 & os27 & os28 & os29 & os30 & os32 & os45 \\
\hline os26 & $\mathrm{r}$ & 1.00 & 0.44 & 0.42 & 0.50 & 0.40 & 0.36 & 0.45 \\
& $\mathrm{p}$ & & 0.00 & 0.00 & 0.00 & 0.00 & 0.00 & 0.00 \\
& $\mathrm{~N}$ & 583.00 & 583.00 & 583.00 & 583.00 & 583.00 & 583.00 & 583.00 \\
os27 & $\mathrm{r}$ & 0.44 & 1.00 & 0.53 & 0.40 & 0.39 & 0.37 & 0.37 \\
& $\mathrm{p}$ & 0.00 & & 0.00 & 0.00 & 0.00 & 0.00 & 0.00 \\
& $\mathrm{~N}$ & 583.00 & 583.00 & 583.00 & 583.00 & 583.00 & 583.00 & 583.00 \\
os28 & $\mathrm{r}$ & 0.42 & 0.53 & 1.00 & 0.52 & 0.47 & 0.46 & 0.46 \\
& $\mathrm{p}$ & 0.00 & 0.00 & & 0.00 & 0.00 & 0.00 & 0.00 \\
& $\mathrm{~N}$ & 583.00 & 583.00 & 583.00 & 583.00 & 583.00 & 583.00 & 583.00 \\
os29 & $\mathrm{r}$ & 0.50 & 0.40 & 0.52 & 1.00 & 0.64 & 0.29 & 0.58 \\
& $\mathrm{p}$ & 0.00 & 0.00 & 0.00 & & 0.00 & 0.00 & 0.00 \\
& $\mathrm{~N}$ & 583.00 & 583.00 & 583.00 & 583.00 & 583.00 & 583.00 & 583.00 \\
os30 & $\mathrm{r}$ & 0.40 & 0.39 & 0.47 & 0.64 & 1.00 & 0.36 & 0.51 \\
& $\mathrm{p}$ & 0.00 & 0.00 & 0.00 & 0.00 & & 0.00 & 0.00 \\
& $\mathrm{~N}$ & 583.00 & 583.00 & 583.00 & 583.00 & 583.00 & 583.00 & 583.00 \\
os32 & $\mathrm{r}$ & 0.36 & 0.37 & 0.46 & 0.29 & 0.36 & 1.00 & 0.33 \\
& $\mathrm{p}$ & 0.00 & 0.00 & 0.00 & 0.00 & 0.00 & & 0.00 \\
& $\mathrm{~N}$ & 583.00 & 583.00 & 583.00 & 583.00 & 583.00 & 583.00 & 583.00 \\
os45 & $\mathrm{r}$ & 0.45 & 0.37 & 0.46 & 0.58 & 0.51 & 0.33 & 1.00 \\
& $\mathrm{p}$ & 0.00 & 0.00 & 0.00 & 0.00 & 0.00 & 0.00 & 583.00 \\
& $\mathrm{~N}$ & 583.00 & 583.00 & 583.00 & 583.00 & 583.00 & 583.00 & 5 \\
\hline
\end{tabular}

As a result of the item correlation analysis Factor 1 (responsibilities towards living environment) items were found significant at .00 level. This analysis shows that every item in Factor 1 is highly correlated with each other. 


\subsubsection{Findings about Correlations under Subtests}

Table 6. The Correlations of Items under Factor II (continuing with the responsibility that the child assumed)

\begin{tabular}{llrrrrrr}
\hline & & os33 & os34 & os37 & os 44 & os46 & os 48 \\
\hline os33 & $\mathrm{r}$ & 1.00 & 0.32 & 0.28 & 0.35 & 0.29 & 0.34 \\
& $\mathrm{p}$ & & 0.00 & 0.00 & 0.00 & 0.00 & 0.00 \\
& $\mathrm{~N}$ & 580.00 & 580.00 & 580.00 & 579.00 & 580.00 & 580.00 \\
os34 & $\mathrm{r}$ & 0.32 & 1.00 & 0.31 & 0.29 & 0.32 & 0.29 \\
& $\mathrm{p}$ & 0.00 & & 0.00 & 0.00 & 0.00 & 0.00 \\
& $\mathrm{~N}$ & 580.00 & 583.00 & 583.00 & 582.00 & 583.00 & 583.00 \\
os37 & $\mathrm{r}$ & 0.28 & 0.31 & 1.00 & 0.35 & 0.38 & 0.31 \\
& $\mathrm{p}$ & 0.00 & 0.00 & & 0.00 & 0.00 & 0.00 \\
& $\mathrm{~N}$ & 580.00 & 583.00 & 583.00 & 582.00 & 583.00 & 583.00 \\
os44 & $\mathrm{r}$ & 0.35 & 0.29 & 0.35 & 1.00 & 0.50 & 0.46 \\
& $\mathrm{p}$ & 0.00 & 0.00 & 0.00 & & 0.00 & 0.00 \\
& $\mathrm{~N}$ & 579.00 & 582.00 & 582.00 & 582.00 & 582.00 & 582.00 \\
os46 & $\mathrm{r}$ & 0.29 & 0.32 & 0.38 & 0.50 & 1.00 & 0.54 \\
& $\mathrm{p}$ & 0.00 & 0.00 & 0.00 & 0.00 & & 0.00 \\
& $\mathrm{~N}$ & 580.00 & 583.00 & 583.00 & 582.00 & 583.00 & 583.00 \\
os48 & $\mathrm{r}$ & 0.34 & 0.29 & 0.31 & 0.46 & 0.54 & 1.00 \\
& $\mathrm{p}$ & 0.00 & 0.00 & 0.00 & 0.00 & 0.00 & \\
& $\mathrm{~N}$ & 580.00 & 583.00 & 583.00 & 582.00 & 583.00 & 583.00 \\
\hline
\end{tabular}

** Correlation is significant at the 0.01 level (2-tailed).

As a result of the item correlation analysis Factor 2 (continuing with the responsibility that the child assumed) items were found significant at .000 level. This analysis shows that every item in Factor 2 is highly correlated with each other.

Table 7. The Correlations of Items under Factor III (responsibilities towards objects)

\begin{tabular}{rlrrrrr}
\hline & & os39 & \multicolumn{1}{c}{ os10 } & os 22 & os21 & \multicolumn{2}{c}{ os42 } \\
\hline os39 & $\mathrm{r}$ & 1.00 & 0.48 & 0.42 & 0.31 & 0.51 \\
& $\mathrm{p}$ & & 0.00 & 0.00 & 0.00 & 0.00 \\
& $\mathrm{~N}$ & 583.00 & 583.00 & 582.00 & 583.00 & 582.00 \\
os10 & $\mathrm{r}$ & 0.48 & 1.00 & 0.42 & 0.28 & 0.36 \\
& $\mathrm{p}$ & 0.00 & & 0.00 & 0.00 & 0.00 \\
& $\mathrm{~N}$ & 583.00 & 587.00 & 586.00 & 587.00 & 582.00 \\
os22 & $\mathrm{r}$ & 0.42 & 0.42 & 1.00 & 0.49 & 0.30 \\
& $\mathrm{p}$ & 0.00 & 0.00 & & 0.00 & 0.00 \\
& $\mathrm{~N}$ & 582.00 & 586.00 & 586.00 & 586.00 & 581.00 \\
os21 & $\mathrm{r}$ & 0.31 & 0.28 & 0.49 & 1.00 & 0.22 \\
& $\mathrm{p}$ & 0.00 & 0.00 & 0.00 & & 0.00 \\
& $\mathrm{~N}$ & 583.00 & 587.00 & 586.00 & 587.00 & 582.00 \\
os42 & $\mathrm{r}$ & 0.51 & 0.36 & 0.30 & 0.22 & 1.00 \\
& $\mathrm{p}$ & 0.00 & 0.00 & 0.00 & 0.00 & \\
& $\mathrm{~N}$ & 582.00 & 582.00 & 581.00 & 582.00 & 582.00 \\
$* *$
\end{tabular}


As a result of the item correlation analysis Factor 3 (responsibilities towards objects) items were found significant at .000 level. This analysis shows that every item in Factor 3 is highly correlated with each other.

Table 8. The Correlations of Items Under Factor 4 (responsibility towards natural environment)

\begin{tabular}{rlrrrr}
\hline & & os17 & os19 & os 11 & os12 \\
\hline os17 & $\mathrm{r}$ & 1.00 & 0.62 & 0.54 & 0.44 \\
& $\mathrm{p}$ & & 0.00 & 0.00 & 0.00 \\
& $\mathrm{~N}$ & 582.00 & 580.00 & 579.00 & 582.00 \\
os 19 & $\mathrm{r}$ & 0.62 & 1.00 & 0.52 & 0.35 \\
& $\mathrm{p}$ & 0.00 & & 0.00 & 0.00 \\
& $\mathrm{~N}$ & 580.00 & 581.00 & 578.00 & 581.00 \\
os 11 & $\mathrm{r}$ & 0.54 & 0.52 & 1.00 & 0.42 \\
& $\mathrm{p}$ & 0.00 & 0.00 & & 0.00 \\
& $\mathrm{~N}$ & 579.00 & 578.00 & 581.00 & 581.00 \\
os12 & $\mathrm{r}$ & 0.44 & 0.35 & 0.42 & 1.00 \\
& $\mathrm{p}$ & 0.00 & 0.00 & 0.00 & \\
& $\mathrm{~N}$ & 582.00 & 581.00 & 581.00 & 586.00 \\
\hline
\end{tabular}

** Correlation is significant at the 0.01 level (2-tailed).

As a result of the item correlation analysis Factor 4 (responsibility towards natural environment) items were found significant at .000 level. This analysis shows that every item in Factor 4 is highly correlated with each other.

Table 9. The Correlations of Items Under Factor V (responsibilities about hygiene)

\begin{tabular}{rlrrrr}
\hline & & os1 & os 5 & os6 & os7 \\
\hline os1 & $\mathrm{r}$ & 1.00 & 0.21 & 0.28 & 0.14 \\
& $\mathrm{p}$ & & 0.00 & 0.00 & 0.00 \\
& $\mathrm{~N}$ & 587.00 & 586.00 & 586.00 & 587.00 \\
os5 & $\mathrm{r}$ & 0.21 & 1.00 & 0.46 & 0.42 \\
& $\mathrm{p}$ & 0.00 & & 0.00 & 0.00 \\
& $\mathrm{~N}$ & 586.00 & 586.00 & 585.00 & 586.00 \\
os6 & $\mathrm{r}$ & 0.28 & 0.46 & 1.00 & 0.37 \\
& $\mathrm{p}$ & 0.00 & 0.00 & & 0.00 \\
& $\mathrm{~N}$ & 586.00 & 585.00 & 586.00 & 586.00 \\
os7 & $\mathrm{r}$ & 0.14 & 0.42 & 0.37 & 1.00 \\
& $\mathrm{p}$ & 0.00 & 0.00 & 0.00 & \\
& $\mathrm{~N}$ & 587.00 & 586.00 & 586.00 & 587.00 \\
\hline
\end{tabular}

** Correlation is significant at the 0.01 level (2-tailed).

As a result of the item correlation analysis Factor 5 (responsibilities about hygiene) items were found significant at .000 level. This analysis shows that every item in Factor 5 is highly correlated with each other.

Table 10. The Correlations of Items under Factor 6 (responsibilities at home)

\begin{tabular}{rlrrrr}
\hline & & os24 & os 25 & os 8 & os 31 \\
\hline os24 & $\mathrm{r}$ & 1.00 & 0.79 & 0.31 & 0.41 \\
& $\mathrm{p}$ & & 0.00 & 0.00 & 0.00 \\
& $\mathrm{~N}$ & 587.00 & 587.00 & 586.00 & 582.00 \\
$\cos 25$ & $\mathrm{r}$ & 0.79 & 1.00 & 0.32 & 0.39 \\
& $\mathrm{p}$ & 0.00 & & 0.00 & 0.00 \\
& $\mathrm{~N}$ & 587.00 & 587.00 & 586.00 & 582.00 \\
os8 & $\mathrm{r}$ & 0.31 & 0.32 & 1.00 & 0.25 \\
& $\mathrm{p}$ & 0.00 & 0.00 & & 0.00 \\
& $\mathrm{~N}$ & 586.00 & 586.00 & 586.00 & 581.00 \\
os31 & $\mathrm{r}$ & 0.41 & 0.39 & 0.25 & 1.00 \\
& $\mathrm{p}$ & 0.00 & 0.00 & 0.00 & \\
& $\mathrm{~N}$ & 582.00 & 582.00 & 581.00 & 582.00 \\
\hline
\end{tabular}

** Correlation is significant at the 0.01 level (2-tailed).

As a result of the item correlation analysis Factor 6 (responsibilities at home) items were found significant 
at .000 level. This analysis shows that every item in Factor 6 is highly correlated with each other.

Table 11. The Correlations of Items under Factor VII (responsibilities towards the society)

\begin{tabular}{rrrrr}
\hline & & os20 & os 16 & os 23 \\
\hline os20 & $\mathrm{r}$ & 1.00 & 0.63 & 0.33 \\
& $\mathrm{p}$ & & 0.00 & 0.00 \\
& $\mathrm{~N}$ & 587.00 & 587.00 & 587.00 \\
$\cos 16$ & $\mathrm{r}$ & 0.63 & 1.00 & 0.36 \\
& $\mathrm{p}$ & 0.00 & & 0.00 \\
& $\mathrm{~N}$ & 587.00 & 587.00 & 587.00 \\
$\cos 23$ & $\mathrm{r}$ & 0.33 & 0.36 & 1.00 \\
& $\mathrm{p}$ & 0.00 & 0.00 & \\
& $\mathrm{~N}$ & 587.00 & 587.00 & 587.00 \\
\hline
\end{tabular}

** Correlation is significant at the 0.01 level (2-tailed).

As a result of the item correlation analysis Factor 7 (responsibilities towards the society) items were found significant at .000 level. This analysis shows that every item in Factor 7 are highly correlated with each other.

Table 12. The Correlations of Items under Factor 8 (responsibilities toward others)

\begin{tabular}{cccc}
\hline & & os 14 & os 15 \\
\hline \multirow{3}{*}{ os14 } & $\mathrm{r}$ & 1.00 & 0.69 \\
& $\mathrm{p}$ & & 0.00 \\
& $\mathrm{~N}$ & 587.00 & 587.00 \\
\multirow{3}{*}{ os15 } & $\mathrm{r}$ & 0.69 & 1.00 \\
& $\mathrm{p}$ & 0.00 & \\
& $\mathrm{~N}$ & 587.00 & 587.00 \\
\hline
\end{tabular}

** Correlation is significant at the 0.01 level (2-tailed).

As a result of the item correlation analysis Factor 8 (responsibility toward others) items were found significant at .000 level. This analysis shows that every item in Factor 8 is highly correlated with each other.

Table 13. The Correlations of Items under Factor 9 (responsibility toward body needs)

\begin{tabular}{rlrrr}
\hline & & os9 & os 40 & os 41 \\
\hline os9 & $\mathrm{r}$ & 1.00 & 0.24 & 0.35 \\
& $\mathrm{p}$ & & 0.00 & 0.00 \\
& $\mathrm{~N}$ & 587.00 & 583.00 & 582.00 \\
$\sin 40$ & $\mathrm{r}$ & 0.24 & 1.00 & 0.27 \\
& $\mathrm{p}$ & 0.00 & & 0.00 \\
& $\mathrm{~N}$ & 583.00 & 583.00 & 582.00 \\
os41 & $\mathrm{r}$ & 0.35 & 0.27 & 1.00 \\
& $\mathrm{p}$ & 0.00 & 0.00 & \\
& $\mathrm{~N}$ & 582.00 & 582.00 & 582.00 \\
\hline
\end{tabular}

** Correlation is significant at the 0.01 level (2-tailed).

As a result of the item correlation analysis Factor 9 (responsibility towards body needs) items were found significant at .000 level. This analysis shows that every item in Factor 9 is highly correlated with each other.

Table 14. The Correlations of Items Under Factor 10 (responsibilities regarding energy saving) 


\begin{tabular}{rrrr}
\hline & & os 35 & os 36 \\
\hline os35 & $\mathrm{r}$ & 1.00 & 0.44 \\
& $\mathrm{p}$ & & 0.00 \\
& $\mathrm{~N}$ & 582.00 & 581.00 \\
$\cos 36$ & $\mathrm{r}$ & 0.44 & 1.00 \\
& $\mathrm{p}$ & 0.00 & \\
& $\mathrm{~N}$ & 581.00 & 582.00 \\
\hline
\end{tabular}

** Correlation is significant at the 0.01 level (2-tailed).

As a result of the item correlation analysis Factor 10(responsibility regarding energy saving) items were found significant at .000 level. This analysis shows that every item in Factor 10 is highly correlated with each other.

Items that are under the sub-dimensions identified significantly high correlations with each other. After the correlation analysis, independent samples t-test was conducted in order to determine the meaningful difference between the top and the bottom of $\% 27$ groups.

The \%27 upper and lower levels of the scale are given at Table 15 below.

Table 15. Scale's Item Discrimination Values for Top and Bottom \%27 Group

\begin{tabular}{|c|c|c|c|c|c|c|c|c|c|}
\hline & Upper lower & $\mathrm{N}$ & Mean & $\begin{array}{c}\text { Std. } \\
\text { Deviation }\end{array}$ & $\begin{array}{c}\text { Levene's } \\
\text { F }\end{array}$ & $\begin{array}{c}\text { Levene's } \\
\text { sig. }\end{array}$ & $\mathrm{t}$ & $\mathrm{df}$ & $\begin{array}{c}\text { Sig } \\
\text { (2-tailed) }\end{array}$ \\
\hline \multirow[t]{2}{*}{ os1 } & 1.00 & 159 & 3.48 & 0.95 & 0.853 & 0.356 & -6.751 & 314 & 0.000 \\
\hline & 2.00 & 157 & 4.17 & 0.85 & & & & & \\
\hline \multirow[t]{2}{*}{ os2 } & 1.00 & 159 & 3.96 & 1.11 & 79.777 & 0.000 & -8.623 & 224.414 & 0.000 \\
\hline & 2.00 & 156 & 4.80 & 0.51 & & & & & \\
\hline \multirow[t]{2}{*}{ os5 } & 1.00 & 158 & 3.87 & 1.029 & 106.053 & 0.000 & -10.606 & 215.327 & 0.000 \\
\hline & 2.00 & 157 & 4.82 & 0.45 & & & & & \\
\hline \multirow[t]{2}{*}{ os6 } & 1.00 & 159 & 3.63 & 1.08 & 99.008 & 0.000 & -12.068 & 222.658 & 0.000 \\
\hline & 2.00 & 157 & 4.76 & 0.50 & & & & & \\
\hline \multirow[t]{2}{*}{ os7 } & 1.00 & 159 & 4.20 & 0.89 & 121.144 & 0.000 & -9.299 & 222.208 & 0.000 \\
\hline & 2.00 & 157 & 4.92 & 0.41 & & & & & \\
\hline \multirow[t]{2}{*}{ os8 } & 1.00 & 159 & 3.18 & 1.39 & 90.462 & 0.000 & -12.207 & 229.428 & 0.000 \\
\hline & 2.00 & 157 & 4.67 & 0.67 & & & & & \\
\hline \multirow[t]{2}{*}{ os9 } & 1.00 & 159 & 3.45 & 1.20 & 31.849 & 0.000 & -9.149 & 273.706 & 0.000 \\
\hline & 2.00 & 157 & 4.50 & 0.79 & & & & & \\
\hline \multirow[t]{2}{*}{ os 10} & 1.00 & 159 & 3.35 & 1.13 & 48.309 & 0.000 & -12.548 & 251.686 & 0.000 \\
\hline & 2.00 & 157 & 4.64 & 0.64 & & & & & \\
\hline \multirow[t]{2}{*}{ os11 } & 1.00 & 158 & 3.33 & 1.17 & 24.416 & 0.000 & -11.379 & 273.173 & 0.000 \\
\hline & 2.00 & 156 & 4.60 & 0.78 & & & & & \\
\hline \multirow[t]{2}{*}{ os 12} & 1.00 & 159 & 3.59 & 0.89 & 58.654 & 0.000 & -14.424 & 255.745 & 0.000 \\
\hline & 2.00 & 157 & 4.77 & 0.52 & & & & & \\
\hline \multirow[t]{2}{*}{ os 14} & 1.00 & 159 & 3.39 & 1.61 & 92.609 & 0.000 & -8.366 & 264.477 & 0.000 \\
\hline & 2.00 & 157 & 4.65 & 1.00 & & & & & \\
\hline \multirow[t]{2}{*}{ os 15} & 1.00 & 159 & 3.28 & 1.27 & 3.054 & 0.082 & -7.130 & 314 & 0.000 \\
\hline & 2.00 & 157 & 4.24 & 1.13 & & & & & \\
\hline \multirow[t]{2}{*}{ os 16} & 1.00 & 159 & 3.68 & 1.17 & 154.558 & 0.000 & -11.809 & 199.593 & 0.000 \\
\hline & 2.00 & 157 & 4.85 & 0.43 & & & & & \\
\hline \multirow[t]{2}{*}{ os17 } & 1.00 & 158 & 3.37 & 1.15 & 14.295 & 0.000 & -10.168 & 293.188 & 0.000 \\
\hline & 2.00 & 157 & 4.54 & 0.87 & & & & & \\
\hline \multirow[t]{2}{*}{ os 19} & 1.00 & 158 & 3.30 & 1.18 & 11.028 & 0.001 & -10.421 & 297.995 & 0.000 \\
\hline & 2.00 & 156 & 4.55 & 0.93 & & & & & \\
\hline \multirow[t]{2}{*}{ os 20} & 1.00 & 159 & 3.89 & 1.21 & 179.335 & 0.000 & -9.611 & 196.751 & 0.000 \\
\hline & 2.00 & 157 & 4.87 & 0.43 & & & & & \\
\hline \multirow[t]{2}{*}{ os 21} & 1.00 & 159 & 3.91 & 0.99 & 87.452 & 0.000 & -11.098 & 218.687 & 0.000 \\
\hline & 2.00 & 157 & 4.87 & 0.44 & & & & & \\
\hline
\end{tabular}




\begin{tabular}{|c|c|c|c|c|c|c|c|c|c|}
\hline & Upper lower & $\mathrm{N}$ & Mean & $\begin{array}{c}\text { Std. } \\
\text { Deviation }\end{array}$ & $\begin{array}{c}\text { Levene's } \\
\text { F }\end{array}$ & $\begin{array}{l}\text { Levene's } \\
\text { sig. }\end{array}$ & $\mathrm{t}$ & $\mathrm{df}$ & $\begin{array}{c}\text { Sig } \\
\text { (2-tailed) }\end{array}$ \\
\hline \multirow[t]{2}{*}{ os 22} & 1.00 & 159 & 3.78 & 0.98 & 100.972 & 0.000 & -12.430 & 224.615 & 0.000 \\
\hline & 2.00 & 156 & 4.85 & 0.46 & & & & & \\
\hline \multirow[t]{2}{*}{ os 23} & 1.00 & 159 & 3.54 & 0.93 & 40.157 & 0.000 & -13.047 & 275.510 & 0.000 \\
\hline & 2.00 & 157 & 4.69 & 0.62 & & & & & \\
\hline \multirow[t]{2}{*}{ os 24} & 1.00 & 159 & 3.06 & 0.98 & 0.027 & 0.869 & -12.461 & 314 & 0.000 \\
\hline & 2.00 & 157 & 4.33 & 0.82 & & & & & \\
\hline \multirow[t]{2}{*}{ os 25} & 1.00 & 159 & 2.75 & 1.02 & 0.001 & 0.972 & -12.386 & 314 & 0.000 \\
\hline & 2.00 & 157 & 4.12 & 0.94 & & & & & \\
\hline \multirow[t]{2}{*}{ os26 } & 1.00 & 158 & 2.08 & 0.99 & 0.373 & 0.542 & -15.362 & 311 & 0.000 \\
\hline & 2.00 & 155 & 3.78 & 0.97 & & & & & \\
\hline \multirow[t]{2}{*}{ os 27} & 1.00 & 158 & 2.88 & 1.20 & 12.799 & 0.000 & -13.749 & 281.903 & 0.000 \\
\hline & 2.00 & 155 & 4.48 & 0.84 & & & & & \\
\hline \multirow[t]{2}{*}{ os 28} & 1.00 & 158 & 3.13 & 0.98 & 20.757 & 0.000 & -17.384 & 254.728 & 0.000 \\
\hline & 2.00 & 155 & 4.72 & 0.58 & & & & & \\
\hline \multirow[t]{2}{*}{ os 29} & 1.00 & 158 & 2.70 & 0.97 & 7.939 & 0.005 & -18.532 & 288.855 & 0.000 \\
\hline & 2.00 & 155 & 4.48 & 0.72 & & & & & \\
\hline \multirow[t]{2}{*}{ os 30} & 1.00 & 158 & 2.86 & 0.94 & 0.007 & 0.933 & -16.109 & 311 & 0.000 \\
\hline & 2.00 & 155 & 4.45 & 0.80 & & & & & \\
\hline \multirow[t]{2}{*}{ os 31} & 1.00 & 158 & 2.60 & 1.08 & 0.688 & 0.407 & -12.738 & 311 & 0.000 \\
\hline & 2.00 & 155 & 4.10 & 1.00 & & & & & \\
\hline \multirow[t]{2}{*}{ os 32} & 1.00 & 158 & 3.28 & 0.95 & 7.323 & 0.007 & -13.325 & 292.880 & 0.000 \\
\hline & 2.00 & 155 & 4.55 & 0.72 & & & & & \\
\hline \multirow[t]{2}{*}{ os33 } & 1.00 & 158 & 2.71 & 1.23 & 2.909 & 0.089 & -11.168 & 311 & 0.000 \\
\hline & 2.00 & 155 & 4.17 & 1.08 & & & & & \\
\hline \multirow[t]{2}{*}{ os34 } & 1.00 & 158 & 2.67 & 1.19 & 2.639 & 0.105 & -11.642 & 311 & 0.000 \\
\hline & 2.00 & 155 & 4.16 & 1.08 & & & & & \\
\hline \multirow{2}{*}{ os35 } & 1.00 & 157 & 3.09 & 1.14 & 9.244 & 0.003 & -13.067 & 286.471 & 0.000 \\
\hline & 2.00 & 155 & 4.57 & 0.84 & & & & & \\
\hline \multirow[t]{2}{*}{ os36 } & 1.00 & 157 & 3.37 & 1.24 & 61.567 & 0.000 & -10.914 & 252.146 & 0.000 \\
\hline & 2.00 & 155 & 4.62 & 0.72 & & & & & \\
\hline \multirow[t]{2}{*}{ os 37} & 1.00 & 158 & 3.29 & 0.94 & 8.992 & 0.003 & -13.918 & 288.489 & 0.000 \\
\hline & 2.00 & 155 & 4.59 & 0.69 & & & & & \\
\hline \multirow[t]{2}{*}{ os39 } & 1.00 & 158 & 3.14 & 1.15 & 42.612 & 0.000 & -14.570 & 243.313 & 0.000 \\
\hline & 2.00 & 155 & 4.67 & 0.63 & & & & & \\
\hline \multirow[t]{2}{*}{ os40 } & 1.00 & 158 & 3.36 & 1.24 & 29.747 & 0.000 & -8.727 & 276.729 & 0.000 \\
\hline & 2.00 & 155 & 4.41 & 0.84 & & & & & \\
\hline \multirow[t]{2}{*}{ os41 } & 1.00 & 158 & 3.75 & 1.11 & 56.772 & 0.000 & -9.877 & 245.943 & 0.000 \\
\hline & 2.00 & 155 & 4.74 & 0.61 & & & & & \\
\hline \multirow[t]{2}{*}{ os42 } & 1.00 & 157 & 3.50 & 1.08 & 56.077 & 0.000 & -12.247 & 247.534 & 0.000 \\
\hline & 2.00 & 155 & 4.72 & 0.61 & & & & & \\
\hline os 44 & 1.00 & 158 & 2.73 & 1.07 & 3.750 & 0.054 & -14.887 & 311 & 0.000 \\
\hline & 2.00 & 155 & 4.38 & 0.88 & & & & & \\
\hline os 45 & 1.00 & 158 & 2.67 & 1.11 & 17.977 & 0.000 & -16.910 & 279.841 & 0.000 \\
\hline & 2.00 & 155 & 4.49 & 0.77 & & & & & \\
\hline os46 & 1.00 & 158 & 2.65 & 1.00 & 1.313 & 0.253 & -15.651 & 311 & 0.000 \\
\hline & 2.00 & 155 & 4.31 & 0.87 & & & & & \\
\hline os 48 & 1.00 & 158 & 3.23 & 1.06 & 30.525 & 0.000 & -14.202 & 259.774 & 0.000 \\
\hline & 2.00 & 155 & 4.64 & 0.64 & & & & & \\
\hline
\end{tabular}

Results of independent sample t-test are given in table 15. Levene's Test for Equality of Variances should be taken into account before the t-test results are used. Levene's test shows whether the variances can be assumed equal or not. T-test results corresponding to the Levene's test results should be used (Field, 2009, p. 340). In table 15, the t-test results are given corresponding to the Levene's test results.

Significantly meaningful difference between the top and the bottom $\% 27$ groups was found as a result of the 
independent $\mathrm{t}$-test analysis ( $<$.000).

\subsection{Findings about Reliability}

3.2.1 Findings about Cronbacah Alpha

Table 16. Results of Item Analysis Item-Total Statistics

\begin{tabular}{|c|c|c|c|}
\hline & Scale Mean if Item Deleted & $\begin{array}{l}\text { Corrected Item-Total } \\
\text { Correlation }\end{array}$ & $\begin{array}{c}\text { Cronbach's Alpha if Item } \\
\text { Deleted }\end{array}$ \\
\hline os1 & 157.16 & 0.26 & 0.92 \\
\hline os2 & 156.58 & 0.39 & 0.92 \\
\hline os5 & 156.63 & 0.41 & 0.92 \\
\hline os6 & 156.74 & 0.46 & 0.92 \\
\hline os7 & 156.36 & 0.41 & 0.92 \\
\hline os8 & 157.04 & 0.43 & 0.92 \\
\hline os9 & 156.99 & 0.40 & 0.92 \\
\hline os 10 & 156.95 & 0.47 & 0.92 \\
\hline os11 & 157.09 & 0.39 & 0.92 \\
\hline os12 & 156.77 & 0.52 & 0.92 \\
\hline os 14 & 156.93 & 0.27 & 0.92 \\
\hline os 15 & 157.29 & 0.25 & 0.92 \\
\hline os16 & 156.61 & 0.48 & 0.92 \\
\hline os 17 & 157.05 & 0.38 & 0.92 \\
\hline os19 & 157.11 & 0.37 & 0.92 \\
\hline os 20 & 156.55 & 0.41 & 0.92 \\
\hline os 21 & 156.54 & 0.42 & 0.92 \\
\hline os 22 & 156.66 & 0.49 & 0.92 \\
\hline os 23 & 156.86 & 0.49 & 0.92 \\
\hline os 24 & 157.30 & 0.47 & 0.92 \\
\hline os 25 & 157.57 & 0.45 & 0.92 \\
\hline os 26 & 158.08 & 0.54 & 0.92 \\
\hline os 27 & 157.27 & 0.50 & 0.92 \\
\hline os 28 & 157.02 & 0.58 & 0.92 \\
\hline os 29 & 157.45 & 0.61 & 0.92 \\
\hline os30 & 157.36 & 0.56 & 0.92 \\
\hline os31 & 157.59 & 0.47 & 0.92 \\
\hline os 32 & 157.05 & 0.48 & 0.92 \\
\hline os 33 & 157.54 & 0.42 & 0.92 \\
\hline os34 & 157.58 & 0.44 & 0.92 \\
\hline os35 & 157.13 & 0.47 & 0.92 \\
\hline os36 & 156.97 & 0.43 & 0.92 \\
\hline os 37 & 156.99 & 0.54 & 0.92 \\
\hline os 39 & 157.04 & 0.54 & 0.92 \\
\hline os 40 & 157.12 & 0.35 & 0.92 \\
\hline os41 & 156.75 & 0.38 & 0.92 \\
\hline os42 & 156.80 & 0.49 & 0.92 \\
\hline os44 & 157.38 & 0.53 & 0.92 \\
\hline os 45 & 157.41 & 0.59 & 0.92 \\
\hline os 46 & 157.52 & 0.55 & 0.92 \\
\hline
\end{tabular}

Cronbach Alpha 0.92

Results of item analysis are given in Table 16. According to the results of analysis Cronbach Alpha coefficient of the scale is as high as 0. 92. Because no item carried the Cronbach Alpha value to a higher value when it is removed as a result of item total and item remainder analyses, all of the items are left in the scale.

Cronbach Alpha values of all sub-dimensions are given in Table 17. 
Table 17. Cronbach Alpha Values of the Factors

\begin{tabular}{cc}
\hline Factors & Cronbach Alpha \\
\hline 1 & 0.84 \\
2 & 0.76 \\
3 & 0.75 \\
4 & 0.80 \\
5 & 0.70 \\
6 & 0.72 \\
7 & 0.81 \\
8 & 0.70 \\
9 & 0.55 \\
10 & 0.60 \\
\hline
\end{tabular}

Cronbach Alpha values of all sub-dimensions on the scale are very high. However $9^{\text {th }}$ and $10^{\text {th }}$ subtests have lower alpha values compared with the rest. However, 9 th and $10^{\text {th }}$ subtests are still found midlevel reliable.

Split half reliability analysis results given in Table 18

Table 18. Split Half Analysis

\begin{tabular}{lllr}
\hline Cronbach's Alpha & Part 1 & Value & .831 \\
& & N of Items & $21(\mathrm{a})$ \\
& Part 2 & Value & .889 \\
& & N of Items & $20(\mathrm{~b})$ \\
& Total N of Items & & 41 \\
Correlation Between Forms & & & .723 \\
Spearman-Brown Coefficient & Equal Length & & .839 \\
& Unequal Length & & .839 \\
Guttman Split-Half Coefficient & & .829 \\
\hline
\end{tabular}

a The items are: os1, os2, os 5, os6, os7, os8, os9, os 10, os11, os12, os14, os15, os16, os17, os 19, os20, os21, os 22 , os 23 , os 24, os 25 .

b The items are: os 26 , os 27 , os 28 , os 29 , os 30 , os 31 , os 32 , os 33 , os 34 , os 35 , os 36 , os 37 , os 39 , os 40 , os 41 , os 42 , os 44 , os 45 , os 46 , os 48 .

In the scale that 29 items were remained as a result of analyses $1^{\text {st }}$ Section reliability was found as Alfa: 0.83 and $2^{\text {nd }}$ Section reliability as Alfa: 0.90 . Such data shows that questions in the scale are coherent with each other. In addition Equal-Length Spearman-Brown, Unequal-Length Spearman-Brown coefficients and Guttman Split Half coefficient are also above 0.60 which also shows reliability of our scale at this point.

\subsubsection{Findings about Test-Retest Analysis}

Results of test-retest analysis are shown in the table 19 below.

Table 19. "Parents' Examination of Responsible Behaviors Of 5-6 Year Old Children"s Scales and Sub-scales test-retest Analysis

\begin{tabular}{ccccccccc}
\hline Pretest-posttest & $\overline{\mathbf{X}}$ & $\mathbf{~ N}$ & $\mathbf{S s}$ & $\mathbf{r}$ & $\mathbf{p}$ & $\mathbf{t}$ & $\mathbf{p}$ & $\mathbf{d f}$ \\
\hline OF1-SF1 & 3.48 & 30.00 & 0.64 & 0.73 & 0.00 & -0.26 & 0.80 & 29 \\
& 3.50 & 30.00 & 0.71 & & & & & \\
OF2-SF2 & 3.85 & 30.00 & 0.64 & 0.53 & 0.00 & 0.06 & 0.95 & 29 \\
& 3.84 & 30.00 & 0.57 & & & & & \\
OF3-SF3 & 4.17 & 30.00 & 0.69 & 0.69 & 0.00 & -1.01 & 0.32 & 29 \\
& 4.27 & 30.00 & 0.67 & & & & & \\
OF4-SF4 & 4.23 & 30.00 & 0.62 & 0.68 & 0.00 & -1.06 & 0.30 & 29 \\
& 4.33 & 30.00 & 0.57 & & & & & \\
OF5-SF5 & 4.19 & 30.00 & 0.58 & 0.82 & 0.00 & -2.03 & 0.05 & 29 \\
OF6-SF6 & 4.31 & 30.00 & 0.58 & & & & \\
& 3.52 & 30.00 & 0.69 & 0.50 & 0.01 & -0.78 & 0.44 & 29
\end{tabular}




\begin{tabular}{ccccccccc}
\hline Pretest-posttest & & $\mathbf{N}$ & $\mathbf{s S}$ & $\mathbf{r}$ & $\mathbf{p}$ & $\mathbf{t}$ & $\mathbf{p}$ & df \\
\hline & 3.62 & 30.00 & 0.72 & & & & & \\
OF7-SF7 & 4.20 & 30.00 & 0.65 & 0.39 & 0.03 & 0.28 & 0.78 & 29 \\
& 4.16 & 30.00 & 0.87 & & & & & \\
OF8-SF8 & 4.40 & 30.00 & 0.68 & 0.60 & 0.00 & -0.38 & 0.70 & 29 \\
& 4.44 & 30.00 & 0.73 & & & & & \\
OF9-SF9 & 3.97 & 30.00 & 0.70 & 0.58 & 0.00 & -1.52 & 0.14 & 29 \\
& 4.14 & 30.00 & 0.71 & & & & & \\
OF10-SF10 & 4.00 & 30.00 & 0.97 & 0.45 & 0.01 & -0.76 & 0.45 & 29 \\
\hline
\end{tabular}

As a result of the test-retest analysis the scale's time resistance was measured and the result was found meaningful at .000 and 0.05 levels (r: 0. 757). Meaningful results were found between results of pretest and posttest results.

When time resistance was evaluated with dependent group $t$ test, a meaningful change in answers was not observed. This demonstrates time resistance of the scale.

\section{Conclusion}

Analyses of the scale devised to examine responsibility of children by their parents resulted that the scale was concentrated in 10 subtests. Cronbach Alpha coefficient of the scale was a high value as 0.92 . The scale was narrowed to 41 items as a result of analyses. Reliability of the $1^{\text {st }}$ section is measured to be alpha: 0.83 and $2^{\text {nd }}$ section as alpha: 0. 90. Such information indicates that questions in the scale are coherent with each other. In addition, Equal-Length Spearman-Brown, Unequal-Length Spearman-Brown coefficients and Guttman Split Half coefficients are found to be above 0.60 . As a result of the test-retest analysis the scale was found to be consistent in time while a meaningful relationship was found between pre-test and post-test results.

Consequently, "Parents' Evaluation of Responsible Behaviors of 5-6 Year Old Children Scale" is a valid and reliable scale.

\section{References}

Akbas, O. (2008). Değer Eğitimi Akımlarına Genel Bir Bakış. Değerler Eğitimi Dergisi , 6(16), 9-27.

Balat, G., \& Dağal, A. (2006). Okul Öncesi Dönemde Değerler Eğitimi Etkinlikleri. Ankara: Kök Yayınc1lık.

Katz, L. (1984). Current Topics in Early Childhood Education. New Jersey: AblexPublication Corporation.

Özden, Y. (2005). Ĕgitimde Yeni Değerler (6th ed.). Ankara: PegemA YAyıncılık.

Polat, Ö. (2005). Okul Öncesi Dönemde Sorumluluk Eğitimi. In A. Oktay, \& Ö. Polat, Okul Öncesi Eğitimde Güncel Konular (pp. 189-197). İstanbul: Morpa.

Polat, Ö. (2010). Okul Öncesi Eğitimde İlköğretime Hazırlık Etkinilikleri. İstanbul: İlkadım Yayınevi.

Rebarber, T. (1996, November 12). Kids source. Retrieved June 12, 2012, from http://www.kidsource.com/kidsource/content/behavior.html

Schulman, K., \& Barnett, S. (2006, March). What Impacts Does Preschool Education Have On Personal Responsibility and Related Social Behavior? Retrieved december 12, 2012, from nieer web site: http://www.nieer.org/publications/nieer-working-papers/what-impacts-does-preschool-education-have-personal-r esponsibility

Yavuzer, H. (2008). Çocuk Eğitimi El Kitabı (23trd ed.). İstanbul: Remzi Kitabevi.

Zembat, R., \& Polat, Ö. (2001). Okul Öncesi Dönemde Çocuğun Sosyalleşmesinde Ailenin Yeri. İstanbul: YA-PA.

\section{(cc) $\mathrm{BY}$}

This work is licensed under a Creative Commons Attribution 3.0 License. 